\title{
ARAŞTIRMA / RESEARCH \\ Personality traits and suicide probability in children and adolescents with specific learning disorder
}

Özgül öğrenme güçlüğü olan çocuk ve ergenlerin intihar olasıllğı ve kişilik özellikleri Dilşad Yıldız Miniksar ${ }^{1}$ iD, Büşra Öz $z^{2}$ iD

${ }^{1}$ Bozok University, Department of Child and Adolescent Psychiatry, Yozgat, Turkey 2Düzce University, Department of Child and Adolescent Psychiatry, Düzce, Turkey

Cukurova Medical Journal 2021;46(3):1245-1256

\section{Abstract}

Purpose: The aim of this study was to examine the personality traits and suicide probability of children and adolescents with a diagnosis of specific learning disorder (SLD).

Materials and Methods: Sixty children with SLD diagnosis and 60 children without SLD diagnosis were included in the study. K-SADS-PL (Kiddie Schedule for Affective Disorders and Schizophrenia-Present and Lifetime version), Wechsler Intelligence Scale for Children-Revised Short Form (WISC-R), Children Depression Inventory (CDI), Suicide Probability Scale (SPS) Personality Inventory for DSM-5-Brief Form-Children (PID-5-BF) scales were used in this study. Results: Factors such as low birth weight, SPS total score and hopelessness subscale, PID-5-BF total score and other subscale scores (excluding antagonism) were higher in the SLD group compared to the control group. There was no significant difference between the groups in terms of CDI score. Children whose mothers smoked during pregnancy had higher frequency of suicidal thoughts and PID-5-BF total scores.

Conclusion: Suicide probability and personality pathologies of children with SLD were found to be higher, regardless of the level of depression. While the low birth weight was important in the etiology of SLD, exposure to smoking during pregnancy was found to be a risk factor for child's suicidal ideation and personality pathologies.

Keywords:. Specific learning disorder (SLD), suicide, personality, pregnancy, children
Öz

Amaç: $\mathrm{Bu}$ çalışmanın amacı Özgül öğrenme güçlüğü (ÖÖG) tanısına sahip çocuk ve ergenlerin kişilik özellikleri ve intihar olasıllklarının incelenmesidir.

Gereç ve Yöntem: Çalıșmaya altmıs ÖÖG tanılı çocuk ve altmış ÖÖG tanısı olmayan çocuk katılmıştır. Bu araştırmada K-SADS-PL (Afektif Bozukluklar ve Şizofreni için Kiddie Çizelgesi-Șimdiki ve Yaşam Boyu versiyonu), Wechsler Çocuklar İçin Zeka Ölçeği-Revize Kısa Formu (WISC-R), Çocuk Depresyon Envanteri (CDI), İntihar Olasıllğı Ölçeği (SPS), Kişilik DSM 5 Kısa Form Çocuklar İçin Envanter (PID-5-BF) kullanılmıștır.

Bulgular: ÖÖG grubunun düşük doğum ağırlığı, SPS total skor ve umutsuzluk alt ölçeği, PID-5-BF total skor ve diğer alt ölçek skorları (karşıtlık hariç) diğer gruptan yüksekti. CDI skor açısından anlamlı farklılık yoktu. Anneleri gebelikte sigara kullanan çocukların intihar düşüncesi ve PID-5-BF total skoru daha yüksekti.

Sonuç: Çalışmamızda ÖÖG tanılı çocukların intihar olasılıkları ve kişilik patolojileri depresyon düzeyinden bağımsız olarak yüksek bulunmuştur. Düşük doğum ağırlığının ÖÖG etyolojisinde önemli olduğu, gebelik döneminde sigaraya maruziyetin, çocuğun intihar düşüncesi ve kişilik patolojisi için bir risk faktörü olduğu tespit edilmiştir.

Anahtar kelimeler: Özgül öğrenme güçlüğü (ÖÖG), intihar, kişilik, gebelik, çocuklar 


\section{INTRODUCTION}

Specific learning disorder (SLD) is a neurodevelopmental disorder characterized by significantly lower than expected reading, writing and arithmetic skills after taking into account the chronological age, measured intelligence level, and education. The prevalence of SLD ranges between 5$15 \%$ in school-age children, and the ratio of males to females is around 2-3 / $1^{1}$. Although the etiology of SLD is not fully understood, genetic factors, history of premature birth, low birth weight, and exposure to nicotine and alcohol in the prenatal period increase the risk of $\mathrm{SLD}^{2}$.

Common problems in SLD include failing at school, as well as learning and adaptation difficulties that can disrupt personal, social, and familial functionalities. The most common comorbidity in SLD is attention deficit and hyperactivity disorder (ADHD), followed by depression, anxiety disorders, suicidal tendencies and substance abuse ${ }^{3}$. Difficulties in reading, math, and writing can cause the child to struggle not only academically, but can also lead to problems such as low self-esteem, hopelessness, behavioral problems, dropping out of school, and difficulties with social skills, neurotic traits, high-state anxiety, finding a job and social adaptation ${ }^{3,4}$. It has been suggested that the prevalence of depression increases in children and adolescents diagnosed with SLD and that they have an increased risk of suicidal behavior ${ }^{5,6}$. Not only psychiatric disorders, but some personality traits such as openness to experience, interpersonal adaptation, and neuroticism may also be related to learning difficulties ${ }^{7-9}$. Since SLD is a multisystem disorder with concomitant personality disorders and involvement of certain brain regions, genetics and environmental factors play a role in its etiology ${ }^{9}$. A strong relationship between difficulty in reading comprehension and impaired cognitive-academic functionality and antisocial behavior has been reported ${ }^{10}$.

We think that the depression levels, suicide risk and personality pathologies of children with SLD who show normal or above-normal development in terms of intelligence, but still fail to achieve expected academic success, and who push themselves to loneliness due to communication difficulties, may be higher than that of their healthy peers. To the best of our knowledge, there are no studies examining the relationship between SLD, personality traits, and suicide probability in children and adolescents. In this study, we aimed to investigate some risk factors in SLD's etiology, and to compare the personality traits and suicide probabilities of children and adolescents with and without SLD diagnosis.

\section{MATERIALS AND METHODS}

\section{Study design and participants}

Among patients that were admitted to the Child and Adolescent Psychiatry Clinic of Yozgat Bozok University between January 2020 and December 2020, 60 patients that met the study criteria, which were age between 11-17 years, being literate, being diagnosed with SLD according to the DSM-5 criteria and receiving follow-up treatment, were included in the study. The sample size was calculated using the G*Power 3.1 program (version 3.1.9; Kiel, Germany) based on the correlation difference between scores. Ay et al. ${ }^{11}$ found a significant difference in the correlation analysis between SPS total and Beck Depression score $(\mathrm{r}=0.637 ; \mathrm{p}<0.001)$. When a 0.01 , power (1- $\beta$ ) 0.90 and correlation coefficient (r) 0.5, the minimum sample size was calculated as a total of 53 patients. In our study, among 102 children with SLD 28 boys and 14 girls between the ages of 7-10 years that did not have literacy skills were excluded from the study, and thus the study was conducted with 60 children and adolescents. The study was approved by the Yozgat Clinical Practice Ethics Board and the written informed consents were obtained from all participants and their legal guardians (2017-KAEK-189_2019.12.11_03).

\section{Procedure}

Between January 2020 and December 2020, 60 children and adolescents diagnosed with SLD and 60 children and adolescents without SLD diagnosis were evaluated. After the approval of the ethics committee, consent was obtained from the parents regarding their children's participation in the study with the "Parent Consent Form" and then data collection tools were applied through face-to-face interviews. In addition to the psychiatric examination, mental capacities of the participants were evaluated with the intelligence test administered by the institutional psychologist.

The diagnosis of SLD was made according to the criteria of the diagnostic and statistical manual of mental disorders (DSM) 5 and affective disorders and schizophrenia for school-age children-present and lifetime version (K-SADS-PL), which is based on 
DSM-IV. The socio-demographic and clinical variables, including age, gender, birth weight, and neuropsychiatric drug use were recorded on a form prepared by the research team. The depressive symptom levels were defined according to the Children Depression Inventory (CDI). Suicide Probability Scale (SPS) was used to evaluate the suicide probability of the participants. Personality Inventory for DSM-5- Brief Form-Children (PID-5$\mathrm{BF}$ ) was used to assess personality pathologies of children. The Wechsler intelligence scale for childrenrevised (WISC-R) was used to assess the intelligence level of the study groups. Meanwhile, patients with WISC-R $\leq 80$, autism spectrum disorders or impairment in vision or speech due to which learning difficulties could occur, and patients that refused to give informed consent were excluded from the study. Cases with WISC-R $\leq 80$ were excluded from the study to determine the power of WISCR in predicting SLD and to exclude cases with mental capacity that could prevent the patients from filling out questionnaires ${ }^{12}$. The same exclusion criteria was applied to the control group, except for the diagnosis of SLD.

\section{Measures}

\section{Sociodemographic data questionnaire}

This questionnaire was developed to determine participants' sociodemographic characteristics (age, gender, birth weight and neuropsychiatric drug use, maternal smoking during pregnancy).

K-SADS-PL (Kiddie Schedule for Affective Disorders and Schizophrenia-Present and Lifetime version)

The K-SADS-PL is a widely used semi-structured diagnostic interview tool used to assess current and past episodes of child and adolescent psychiatric disorders. The Turkish version of the K-SADS-PL has good test-retest and inter-rater reliability ${ }^{13,14}$. In this study, K-SADS-PL was used together with DSM-5 diagnostic criteria to determine psychiatric diagnoses in addition to SLD.

\section{Wechsler Intelligence Scale for Children-Revised Short Form (WISC-R)}

This scale measures the intelligence levels of children between the ages of 6 and 17. It was adapted to Turkish by Uluc et al. ${ }^{15}$. In the reliability study of WISC-R on Turkish children, the semi-reliability of the tests was found to be 0.97 for the verbal section,
0.93 for the performance section, and 0.97 for the total section. These values show that the Turkish version of WISC-R is highly reliable ${ }^{16}$.

\section{Children Depression Inventory (CDI)}

CDI is a self-report depression scale modeled after Adult Beck Depression Inventory ${ }^{17}$, which is used to assess depressive symptoms. Twenty-seven multiplechoice items evaluate the severity of depressive symptoms during the previous 2 weeks. The scale is widely used and has demonstrated good concurrent validity and reliability in Turkish children and adolescents ${ }^{18}$. The scale is scored between $0-2$ with the maximum score of 54 . The high score indicates the severity of the depression level. The cut-off value for Turkish patients was 19 18.

\section{Suicide Probability Scale (SPS)}

It is a four-point Likert-type self-assessment scale with 36 items that was developed by Cull and Gill ${ }^{19}$. Adaptation to Turkish, validity, and reliability studies were carried out by Atli et al. ${ }^{20}$ The aim of the scale is to assess suicide risk in adolescents and adults. It includes four subscales: hopelessness, suicidal ideation, negative self-evaluation, and hostility. The answers given to the items in the original form of the scale were "never or rarely" (1), "sometimes" (2), "often" (3) and "frequently or always" (4). A score between 36 and 144 can be obtained from the scale. A different score sum is obtained for each subscale, while the sum of all the scores gives the score of general suicide probability. The higher scores indicate a higher probability of suicide. In the study conducted with psychiatric patients, people with suicide attempts, and controls, the Cronbach alpha internal consistency coefficient of SPS was 0.93 , and the test-retest reliability coefficient was $0.92^{19}$.

\section{Personality Inventory for DSM-5-Brief Form - Children (PID-5-BF)}

The Personality Inventory for DSM-5-Brief FormChildren (PID-5-BF) ${ }^{21}$ is a 25 -item self-rated scale for children aged 11 to 17 years old. The questions tap into five different personality domains according to the DSM-5 model for personality disorders ${ }^{1}$. Five maladaptive variants of personality-trait domains are assessed: negative affectivity, detachment, antagonism, disinhibition, and psychoticism. Each trait domain consists of five items rated on a 4-point scale (from $0=$ very false or often false to $3=$ very true or often true). The overall score ranges from 0 to 75 , with higher scores suggesting greater overall 
personality dysfunction. Each trait domain has a range of scores from 0 to 15 , with higher scores indicating greater dysfunction in that particular personality trait domain. The PID-5-BF has been validated in Turkey ${ }^{22}$. In the present study, Cronbach's alpha for the PID-5-BF total score was 0.91, and Cronbach's alpha for the PID-5-BF domains ranged from 0.77 (detachment) to 0.85 (antagonism).

\section{Statistical analysis}

Statistical analysis was carried out with SPSS version 17.0 program. The compliance of the variables to normal distribution was examined using histogram graphics and Kolmogorov-Smirnov test. Mean, standard deviation, and median values were used while presenting descriptive analyzes. Categorical variables were compared using the Pearson ChiSquare Test. Mann Whitney U Test was used when evaluating nonparametric groups. Correlations between scales and subscales in the groups were analyzed using the Spearman's correlation test. The p-value of $>0.05$ was considered as statistically significant.

\section{RESULTS}

The comparison of sociodemographic and clinical characteristics of the groups revealed that rate of comorbid psychiatric diagnoses was higher in the SLD group $(p=0.000)$ (Table 1). Depression, $\mathrm{ADHD}$, and anxiety disorder rates in the control group were $10 \%, 6.6 \%$ and $5 \%$, respectively. In the SLD group, 61.6\% had ADHD, 13.3\% had ADHD + depression, $6.6 \%$ had depression, and $1.6 \%$ had behavior disorder, depression + anxiety disorder, and stuttering comorbidity. While the rate of ADHD alone and ADHD + depression comorbidity was higher in SLD patients, the rate of depression alone was lower $(p=0.000)$ (Table 1). The rate of neuropsychiatric drug use was higher in SLD group $(p=0.001)$. Neuropsychiatric drugs used by patients were selective serotonin reuptake inhibitors (SSRIs), stimulants, antipsychotics, antiepileptics and / or their combined forms.

In this study, the birth weight range of 2500-4000 grams was considered normal ${ }^{23}$. Low birth weight rate was significantly higher in SLD group $(p=0.048)$ (Table 1). There was no significant difference between the two groups in terms of gender, somatic disease, maternal smoking during pregnancy, and preterm birth. In the control group, 11 (18.3\%) individuals had somatic diseases: 4 had acne vulgaris, 3 had allergic asthma, 2 had obesity, 1 had adenoid hypertrophy, and 1 had atopic dermatitis. In the SLD group, $10(16.6 \%)$ children had somatic diseases. While 3 of them had epilepsy, the remaining $7 \mathrm{had}$ one of the following: allergic asthma, acute rheumatic fever, scoliosis, familial Mediterranean fever, cerebral palsy, hydrocephalus, and bilateral sensorineural hearing loss.

When the two groups were compared in terms of age and scales, the mean age of the SLD group was lower, while the means of the SPS total score and hopelessness subscale, PID-5-BF total score and negative affectivity, detachment, disinhibition, and psychoticism subscales were higher. There was no significant difference between the two groups in terms of CDI score $(p=0.750)$ (Table 2$)$.

The relationship between scales and subscales in the SLD group was examined using the Spearman correlation test and the results are presented in table 3. There was the same directional correlation between the CDI score and SPS total score and subscales, and PID-5-BF total and subscales; SPS total score and PID-5-BF total and subscales. Moreover, there was a same directional correlation between hopelessness and suicidal ideation, hostility and PID-5-BF total and subscales, between suicidal ideation and hostility, PID-5-BF total and psychoticism, between hostility and PID-5-BF total and all its subscales. There was no correlation between hopelessness and negative self-evaluation, suicidal ideation and negative selfevaluation and all subscales of PID-5-BF (except psychoticism) and between negative self-evaluation and antagonism, PID-5-BF total, and all subscales (Table 3).

The Spearman correlation test was also used to evaluate the relationship between scales and subscales in the control group and the results are presented in table 4 . In the control group, there was the same directional correlation between CDI score, SPS total score and subscales and PID-5-BF total and subscales. Similar correlations were found between suicidal ideation and negative self-evaluation, hostility, PID-5-BF total and all subscales (except antagonism) (Table 4). 
Table 1. Sociodemographic and clinical characteristics of groups

\begin{tabular}{|c|c|c|c|c|c|c|}
\hline & \multicolumn{4}{|c|}{ Specific learning disorder } & \multirow{3}{*}{$p$} \\
\hline & & \multicolumn{2}{|c|}{ Present } & \multicolumn{2}{|c|}{ Absent } & \\
\hline & & $\mathrm{n}$ & $\%$ & $\mathrm{n}$ & $\%$ & \\
\hline \multirow{2}{*}{ Gender } & Male & 31 & $(51.67)$ & 28 & $(46.67)$ & \multirow{2}{*}{0.584} \\
\hline & Female & 29 & $(48.33)$ & 32 & $(53.33)$ & \\
\hline \multirow{2}{*}{ Somatic disease } & Present & 10 & $(16.67)$ & 11 & $(18.33)$ & \multirow{2}{*}{0.810} \\
\hline & Absent & 50 & $(83.33)$ & 49 & $(81.67)$ & \\
\hline \multirow{2}{*}{ Comorbid psychiatric disorder } & Present & 52 & $(86.67)$ & 13 & $(21.67)$ & \multirow{2}{*}{0.000} \\
\hline & Absent & 8 & $(13.33)$ & 47 & $(78.33)$ & \\
\hline \multirow{3}{*}{ Comorbid psychiatric disorder type } & ADHD & 37 & $(75.51)$ & 4 & $(40.00)$ & \multirow{3}{*}{0.000} \\
\hline & Depression & 4 & $(8.16)$ & 6 & $(60.00)$ & \\
\hline & ADHD + Depression & 8 & $(16.33)$ & 0 & $(.00)$ & \\
\hline \multirow{2}{*}{ Neuropsychiatric drug use } & Present & 18 & $(30.00)$ & 4 & $(6.67)$ & \multirow{2}{*}{0.001} \\
\hline & Absent & 42 & $(70.00)$ & 56 & $(93.33)$ & \\
\hline \multirow{3}{*}{ Birth weight } & Low & 15 & $(25.00)$ & 5 & $(8.33)$ & \multirow{3}{*}{0.048} \\
\hline & Normal & 43 & $(71.67)$ & 52 & $(86.67)$ & \\
\hline & High & 2 & $(3.33)$ & 3 & $(5.00)$ & \\
\hline \multirow{2}{*}{ Premature birth history } & Present & 6 & $(10.00)$ & 3 & $(5.00)$ & \multirow{2}{*}{0.298} \\
\hline & Absent & 54 & $(90.00)$ & 57 & $(95.00)$ & \\
\hline \multirow{2}{*}{ Mother's smoking history during pregnancy } & Present & 12 & $(20.00)$ & 6 & $(10.00)$ & \multirow{2}{*}{0.125} \\
\hline & Absent & 48 & $(80.00)$ & 54 & $(90.00)$ & \\
\hline
\end{tabular}

Chi-Square Test

Table 2. Comparison of age and scale scores between the groups

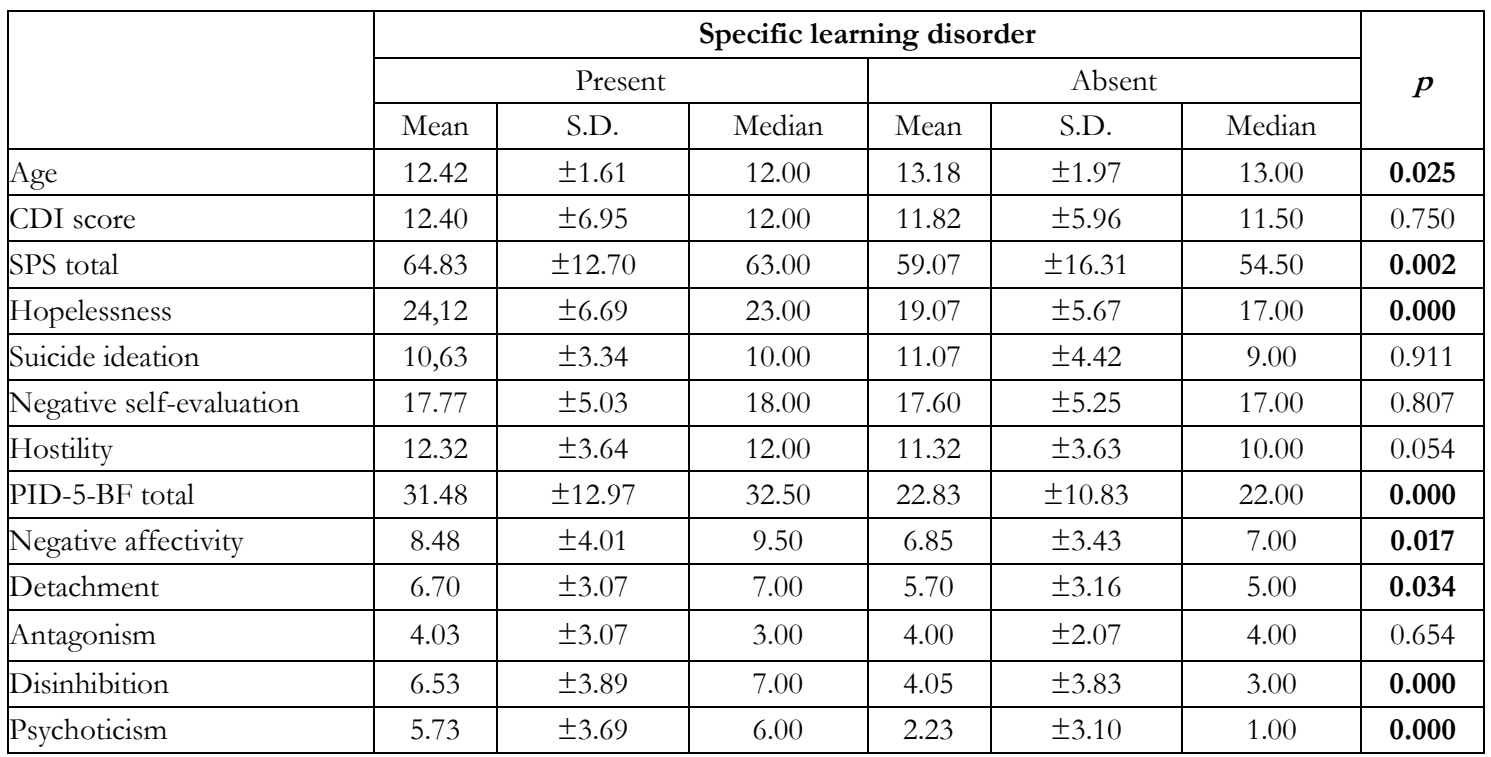

CDI: Children Depression Inventory, SPS: Suicide Probability Scale, PID-5-BF: Personality Inventory for DSM-5-Brief Form-Children, Mann Whitney U Test 
Table 3. Relationship between scales and subscales in SLD group

\begin{tabular}{|c|c|c|c|c|c|c|c|c|c|c|c|c|c|}
\hline SLD present & & $\begin{array}{l}\text { CDI } \\
\text { score }\end{array}$ & $\begin{array}{l}\text { SPS } \\
\text { total }\end{array}$ & $\begin{array}{c}\text { Hopelessne } \\
\text { ss }\end{array}$ & $\begin{array}{l}\text { Suicide } \\
\text { ideation }\end{array}$ & \begin{tabular}{|c|} 
Negative \\
self- \\
evaluation
\end{tabular} & Hostility & $\begin{array}{l}\text { PID-5-BF } \\
\text { total }\end{array}$ & $\begin{array}{l}\text { Negative } \\
\text { affectivity }\end{array}$ & $\begin{array}{c}\text { Detachme } \\
\text { nt }\end{array}$ & $\begin{array}{c}\text { Antagonis } \\
\mathrm{m}\end{array}$ & Disinhibition & Psychoticism \\
\hline \multirow{2}{*}{ CDI score } & r & & 0.538 & 0.388 & 0.359 & \begin{tabular}{|l|}
0.346 \\
\end{tabular} & 0.352 & 0.474 & 0.435 & 0.296 & 0.380 & 0.272 & 0.427 \\
\hline & $p$ & & 0.000 & 0.002 & 0.005 & 0.007 & 0.006 & 0.000 & 0.001 & 0.022 & 0.003 & 0.036 & 0.001 \\
\hline \multirow{2}{*}{ SPS total } & $r$ & & & 0.770 & 0.563 & 0.476 & 0.754 & 0.622 & 0.415 & 0.388 & 0.444 & 0.382 & 0.625 \\
\hline & $p$ & & & 0.000 & 0.000 & 0.000 & 0.000 & 0.000 & 0.001 & 0.002 & 0.000 & 0.003 & 0.000 \\
\hline \multirow{2}{*}{ Hopelessness } & $r$ & & & & 0.402 & 0.001 & 0.550 & 0.541 & 0.397 & 0.374 & 0.350 & 0.317 & 0.580 \\
\hline & $p$ & & & & 0.001 & 0.993 & 0.000 & 0.000 & 0.002 & 0.003 & 0.006 & 0.014 & 0.000 \\
\hline \multirow{2}{*}{\begin{tabular}{|l|} 
Suicide \\
ideation
\end{tabular}} & $r$ & & & & & 0.177 & 0.341 & 0.270 & 0.224 & 0.052 & 0.109 & 0.109 & 0.426 \\
\hline & $p$ & & & & & 0.176 & 0.008 & 0.037 & 0.086 & 0.690 & 0.407 & 0.407 & 0.001 \\
\hline \multirow{2}{*}{$\begin{array}{l}\text { Negative self- } \\
\text { evaluation }\end{array}$} & $r$ & & & & & & 0.191 & 0.143 & 0.073 & 0.074 & 0.126 & 0.156 & 0.077 \\
\hline & p & & & & & & 0.145 & 0.276 & 0.579 & 0.573 & 0.336 & 0.233 & 0.561 \\
\hline \multirow{2}{*}{ Hostility } & $r$ & & & & & & & 0.636 & 0.453 & 0.346 & 0.491 & 0.469 & 0.594 \\
\hline & p & & & & & & & 0.000 & 0.000 & 0.007 & 0.000 & 0.000 & 0.000 \\
\hline \multirow{2}{*}{$\begin{array}{l}\text { PID-5-BF } \\
\text { total }\end{array}$} & $r$ & & & & & & & & 0.764 & 0.707 & 0.657 & 0.761 & 0.718 \\
\hline & $p$ & & & & & & & & 0.000 & 0.000 & 0.000 & 0.000 & 0.000 \\
\hline \multirow{2}{*}{$\begin{array}{l}\text { Negative } \\
\text { affectivity }\end{array}$} & $r$ & & & & & & & & & 0.453 & 0.379 & 0.563 & 0.423 \\
\hline & $p$ & & & & & & & & & & 0.003 & 0.000 & 0.001 \\
\hline \multirow{2}{*}{ Detachment } & $r$ & & & & & & & & & & 0.473 & 0.413 & 0.387 \\
\hline & $p$ & & & & & & & & & & 0.000 & 0.001 & 0.002 \\
\hline \multirow{2}{*}{ Antagonism } & $r$ & & & & & & & & & & & 0.301 & 0.440 \\
\hline & $p$ & & & & & & & & & & & 0.019 & 0.000 \\
\hline \multirow{2}{*}{ Disinhibition } & $r$ & & & & & & & & & & & & 0.446 \\
\hline & $p$ & & & & & & & & & & & & 0.000 \\
\hline \multirow{2}{*}{ Psychoticism } & $r$ & & & & & & & & & & & & \\
\hline & p & & & & & & & & & & & & \\
\hline
\end{tabular}

CDI: Children Depression Inventory, SPS: Suicide Probability Scale, PID-5-BF: Personality Inventory for DSM-5-Brief Form-Children, Spearman correlation test

Table 4. Relationship between scales and subscales in the control group

\begin{tabular}{|c|c|c|c|c|c|c|c|c|c|c|c|c|c|}
\hline \multicolumn{2}{|l|}{ SLD absent } & $\begin{array}{l}\text { CDI } \\
\text { score }\end{array}$ & $\begin{array}{l}\text { SPS } \\
\text { total }\end{array}$ & Hopelessness & $\begin{array}{l}\text { Suicide } \\
\text { ideation }\end{array}$ & $\begin{array}{c}\text { Negative } \\
\text { self- } \\
\text { evaluation }\end{array}$ & Hostility & \begin{tabular}{|l|} 
PID-5- \\
BF total
\end{tabular} & $\begin{array}{l}\text { Negative } \\
\text { affectivity }\end{array}$ & Detachment & Antagonism & Disinhibition & Psychoticism \\
\hline \multirow{2}{*}{ CDI score } & r & & 0.856 & 0.763 & 0.710 & \begin{tabular}{|l|}
0.768 \\
\end{tabular} & 0.498 & 0.708 & 0.744 & 0.520 & 0.324 & 0.491 & 0.503 \\
\hline & $p$ & & 0.000 & 0.000 & 0.000 & 0.000 & 0.000 & 0.000 & 0.000 & 0.000 & 0.012 & 0.000 & 0.000 \\
\hline \multirow{2}{*}{ SPS total } & $r$ & & & 0.842 & 0.794 & 0.921 & 0.524 & 0.757 & 0.699 & 0.450 & 0.369 & 0.546 & 0.610 \\
\hline & p & & & 0.000 & 0.000 & 0.000 & 0.000 & 0.000 & 0.000 & 0.000 & 0.004 & 0.000 & 0.000 \\
\hline \multirow{2}{*}{ Hopelessness } & $r$ & & & & 0.612 & 0.696 & 0.246 & 0.629 & 0.561 & 0.484 & 0.269 & 0.437 & 0.534 \\
\hline & $p$ & & & & 0.000 & 0.000 & 0.058 & 0.000 & 0.000 & 0.000 & 0.038 & 0.000 & 0.000 \\
\hline \multirow{2}{*}{ Suicide ideation } & $r$ & & & & & 0.655 & 0.497 & 0.598 & 0.618 & 0.340 & 0.233 & 0.393 & 0.424 \\
\hline & p & & & & & 0.000 & 0.000 & 0.000 & 0.000 & 0.008 & 0.073 & 0.002 & 0.001 \\
\hline \multirow{2}{*}{$\begin{array}{l}\text { Negative self- } \\
\text { evaluation }\end{array}$} & $r$ & & & & & & 0.407 & 0.674 & 0.662 & 0.387 & 0.312 & 0.472 & 0.547 \\
\hline & $p$ & & & & & & 0.001 & 0.000 & 0.000 & 0.002 & 0.015 & 0.000 & 0.000 \\
\hline \multirow{2}{*}{ Hostility } & $r$ & & & & & & & 0.507 & 0.363 & 0.189 & 0.282 & 0.419 & 0.393 \\
\hline & p & & & & & & & 0.000 & 0.004 & 0.147 & 0.029 & 0.001 & 0.002 \\
\hline \multirow{2}{*}{ PID-5-BF total } & $r$ & & & & & & & & 0.707 & 0.666 & 0.628 & 0.752 & 0.819 \\
\hline & $p$ & & & & & & & & 0.000 & 0.000 & 0.000 & 0.000 & 0.000 \\
\hline \multirow{2}{*}{$\begin{array}{l}\text { Negative } \\
\text { affectivity }\end{array}$} & $r$ & & & & & & & & & 0.667 & 0.276 & 0.295 & 0.390 \\
\hline & p & & & & & & & & & 0.000 & 0.033 & 0.022 & 0.002 \\
\hline \multirow{2}{*}{ Detachment } & $r$ & & & & & & & & & & 0.246 & 0.208 & 0.458 \\
\hline & $p$ & & & & & & & & & & 0.058 & 0.110 & 0.000 \\
\hline \multirow{2}{*}{ Antagonism } & $r$ & & & & & & & & & & & 0.563 & 0.494 \\
\hline & p & & & & & & & & & & & 0,000 & 0.000 \\
\hline \multirow{2}{*}{ Disinhibition } & $r$ & & & & & & & & & & & & 0.704 \\
\hline & p & & & & & & & & & & & & 0.000 \\
\hline \multirow{2}{*}{ Psychoticism } & $r$ & & & & & & & & & & & & \\
\hline & $\bar{p}$ & & & & & & & & & & & & \\
\hline
\end{tabular}

CDI: Children Depression Inventory, SPS: Suicide Probability Scale, PID-5-BF: Personality Inventory for DSM-5-Brief Form-Children, Spearman correlation test 
Comparison of the SLD group with the control group revealed that while there was no significant correlation between hopelessness and negative selfevaluation, between suicidal thoughts and negative self-evaluation, negative affectivity, detachment and disinhibition, and between negative self-evaluation, hostility, and PID-5-BF total and subscales in the SLD group, there was a significant correlation between them in the control group. In addition, there was a significant correlation between hopelessness and hostility, between hostility and detachment, and between detachment and antagonism and disinhibition in the SLD group, but no significant correlation between them in the control group.

Scales were evaluated according to sociodemographic and clinical characteristics, and those with a significant relationships were given O.R values. CDI scores of females were higher than those of males ( $p$
$=0.035)$. CDI score and negative affect were higher in those with somatic diseases $(\mathrm{p}=0.001$ and $\mathrm{p}=$ 0.030 , respectively). Moreover, CDI score ( $\mathrm{p}=$ $0.001)$, SPS total score $(\mathrm{p}=0.000)$ and subscales, PID-5-BF total $(\mathrm{p}=0.000)$ and subscale scores (excluding antagonism) were higher in patients with comorbid psychiatric disorders. CDI score ( $\mathrm{p}=$ 0.006), SPS total score $(\mathrm{p}=0.008)$, hopelessness $(\mathrm{p}=$ $0.002)$, hostility $(\mathrm{p}=0.025)$, PID-5-BF total $(\mathrm{p}=$ $0.006)$, negative affectivity $(p=0.007)$, detachment $(p$ $=0.006)$, and psychoticism $(\mathrm{p}=0.010)$ values were higher in patients treated with neuropsychiatric drug. However, their scores of negative self-evaluation, suicidal ideation, and personality traits such as antagonism and disinhibition were not high. Suicidal ideation $(p=0.020)$ and total PID-5-BF scores $(p=$ 0.046 ) were higher in children and adolescents whose mothers had a history of smoking during pregnancy (Table 5).

Table 5. Relationship between clinical variables and scores of scales and their sub-scales

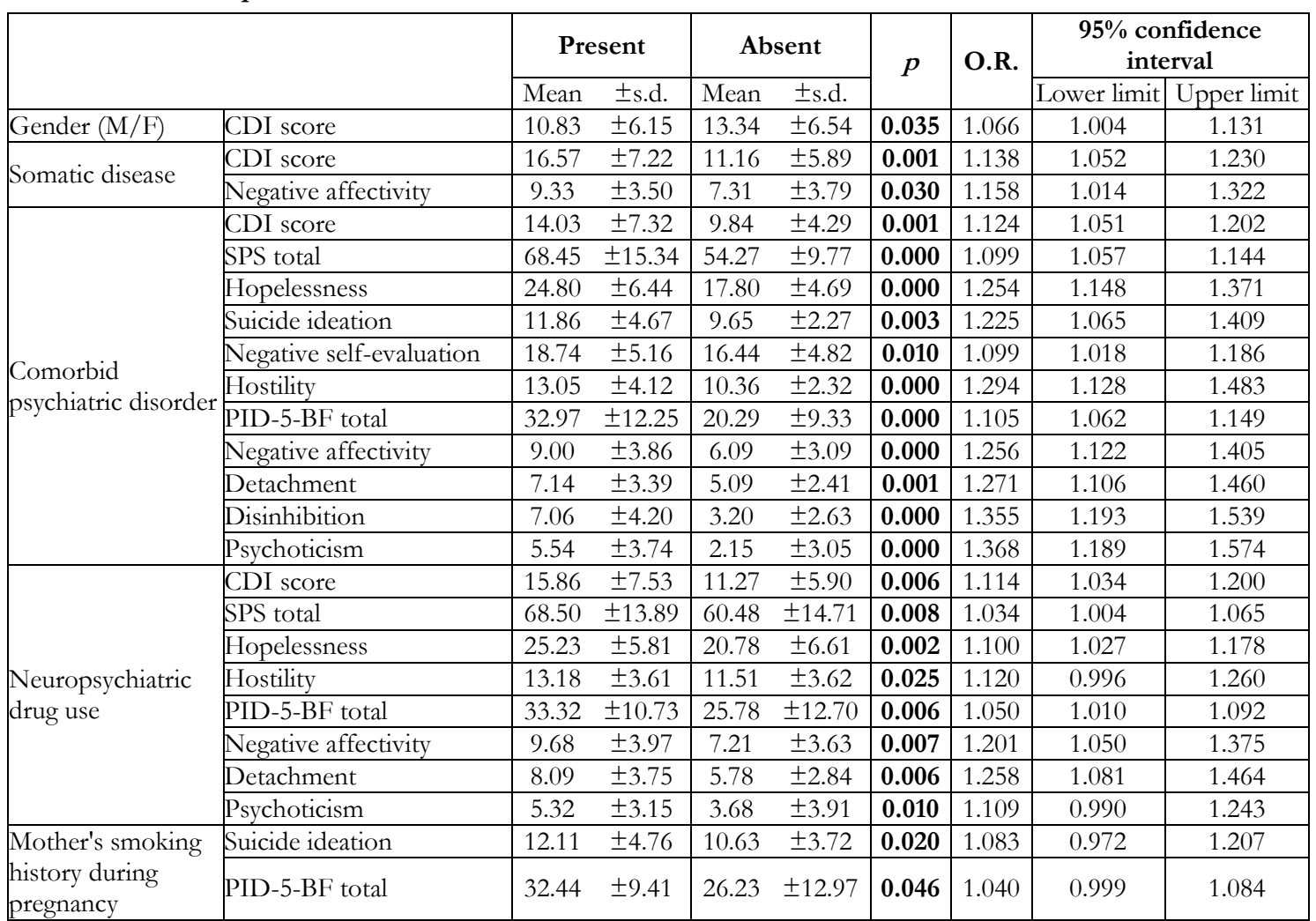

CDI: Children Depression Inventory, SPS: Suicide Probability Scale, PID-5-BF: Personality Inventory for DSM-5-Brief Form-Children, Mann Whitney U Test 


\section{DISCUSSION}

The main purpose of our study was to examine the personality traits and suicide probability of children and adolescents with SLD, while the secondary aim was to reveal the role of some prenatal and birth risk factors in the etiology of SLD. We found that the most common psychiatric diagnosis accompanying SLD was ADHD, and the history of neuropsychiatric drug use and low birth weight was significantly higher in the SLD group. We also found that children with SLD had a high probability of suicide and personality pathologies, regardless of their depressive symptom level. Evaluation of the entire study population showed that depression scores were higher in females and in those with somatic disease. The CDI score, SPS total score and subscales, and PID-5-BF total and subscale scores (excluding antagonism) were higher in patients with comorbid psychiatric disorders. Moreover, among the individuals that were treated with neuropsychiatric drugs all total scale scores were high, but scores for the negative selfevaluation and suicidal ideation subscale and personality traits such as antagonism and disinhibition were low. We also determined that children whose mothers smoked during pregnancy had high suicidal ideation and PID-5-BF total scores.

Studies have shown that premature birth history, low birth weight, and exposure to nicotine and alcohol during the prenatal period increase the risk of SLD ${ }^{2}$. It is inevitable that SLD, which is a neurodevelopmental disorder, is associated with prenatal and perinatal factors. Maternal malnutrition, exposure to risk factors such as smoking, drugs and alcohol can impair normal brain development and function, especially during pregnancy ${ }^{24}$. We found that among these risk factors, only low birth weight increased the risk of SLD in our study. The fact that these data are not supported by objective evidence and that this information is based on maternal anamnesis only may have had an effect. Emotional problems, low self-esteem, peer relations problems, symptoms such as dysthymia, depression, anxiety, stubbornness, behavioral disorder, criminal behavior, antisocial personality disorder and substance abuse in their future life are more common in children with SLD who struggle with academic skills ${ }^{25}$. Therefore, it is an expected finding that the rates of concomitant psychiatric disorders in these children are higher than those without SLD, as in our study. Similar to the literature, we found that the most common comorbid psychiatric diagnosis was $\mathrm{ADHD}^{3}$. The high rate of psychiatric comorbidity and accompanying epilepsy in some of the children with SLD may explain the higher rates of neuropsychiatric drug use compared to the control group. There was no significant difference in terms of CDI scores between the two groups.

While there are studies reporting that depressive symptom level in SLD is generally high, there are other studies indicating that depressive symptoms increase with increasing age, in people with learning disabilities in particular. It has been shown that the problems of children with SLD are not limited to the academics, they experience more difficulties as they get older, their hopelessness levels as well as depression and anxiety scores increase 26,27 . In our study, the lower mean age of the SLD group compared to the control group may be associated with the absence of a significant difference in depression scores. The fact that our study was conducted during the COVID-19 pandemic may also have caused an extra increase in the depression scores of the control group. Because compared to adults, children lack experience and skills in reaching the resources that will meet their social, emotional and behavioral needs and therefore they may experience more depression and helplessness in crisis situations such as pandemics ${ }^{28}$.

Similar to the literature, in our study, the suicide probability of children diagnosed with SLD was high 5,6 . However, the high probability of suicide was not due to depressive symptoms. Apart from the hopelessness subscale of the SPS scales, there was no significant difference between the two groups in other subscales (suicidal ideation, negative selfevaluation, hostility). The negative self-evaluation subscale is related to the person's negative attribution to himself as a result of not being satisfied with his high expectations ${ }^{29}$, while the hostility subscale is related to having hostile feelings towards others, and the suicidal ideation subscale is related to the intense thoughts towards suicide. The hopelessness subscale indicates the individual's general dissatisfaction with life, negative expectations from the future, and feelings of inability to change the conditions. Therefore, children and adolescents that feel hopeless may experience difficulties at school, finding a job, and social adaptation ${ }^{3}$. The high hopelessness subscale score in our study, which causes a high probability of suicide, is similar to findings from other studies that reported that most important variable associated with suicidal ideation is 
hopelessness ${ }^{30}$. Another study has shown that hopelessness is an important cognitive factor that predicts suicidal behavior even when depression is controlled, just as in our study ${ }^{31}$. Studies have found that predictor variables for hostility and suicidal ideation subscales are exposure to violence, selfharm, and suicide attempts in the vicinity. Depression symptoms were also found to predict negative selfevaluation score $^{32}$. The absence of a significant difference in the severity of depression symptoms between the two groups in our study may be explained by the lack of assessment of risk factors that could predict hostility and suicidal ideation in the SLD group, such as self-harm and violence. Because the main determinant of hopelessness in children with SLD is future academic difficulties and concerns about social adaptation ${ }^{3}$.

There was a correlation between SLD and personality pathology level in our study. Sharma et al..$^{33}$ compared children with and without SLD and stated that those diagnosed with SLD were more easily unsettled, more emotional, more cowardly, more pessimistic, had lower frustration tolerance, and could not socialize as easily as other children ${ }^{33}$.

We also found that the means of PID-5-BF total score and negative affect, detachment, disinhibition and psychoticism subscales were higher in the SLD group than in the control group. However, there was no significant difference in the antagonism subscale. The DSM-5 defines personality disorder based on symptoms. In this scale, personality sub-dimensions are maladaptive, that is, incompatible personality traits. Negative affectivity represents hostility and emotional lability; detachment represents skepticism and insincerity, antagonism represents grandiosity, manipulation and hoax, disinhibition represents risk taking, and impulsivity, while psychoticism represents the cognition-perception disorders, disorganized behavior, and unusual beliefs ${ }^{34}$. One of the main characteristics of SLD is that it is a common disorganization state that spreads to the areas of attention, cognition, perception and motor control ${ }^{35}$. A strong relationship between SLD and schizotypal characteristics has been previously reported ${ }^{36}$. It is thought that schizophrenia and SLD have a common neurodevelopmental basis, and one study even reported that the prevalence of reading difficulties is high in the first degree relatives of schizophrenia patients ${ }^{37}$. For this reason, it is not surprising that the psychoticism scores, which represent the dimension of skepticism and include the symptoms of detachment and schizophrenia were high in our SLD group. Considering that these children's moods change more rapidly ${ }^{33}$, the high negative affect score representing emotional lability can be better understood. Hyperactivity and impulsivity in children are predictors of antisocial behaviors in advanced ages, and impulsivity has been shown as a secondary psychiatric problem in SLD 38,39. Impulsivity is personality trait that is commonly associated with suicidal behavior ${ }^{40}$. In addition to the fact that some personality traits are related to SLD, the very high rate of ADHD concomitant with SLD in our study may have increased the scores of these personality traits, especially disinhibition representing impulsivity. The low self-esteem scores in SLD group may be explained by the fact that antagonism subscore associated with grandiosity were not significantly higher than controls ${ }^{25}$.

The evaluation of relationship between the scales showed that the subscales of hopelessness and hostility predicted suicidal ideation in the SLD group and that patients with higher personality pathologies had more intense suicidal ideation. The high level of psychoticism subscale score was found to determine personality pathology and was associated with suicidal ideation. We did not find a significant correlation between negative self-evaluation and hopelessness, suicidal ideation, and personality pathology in the SLD group. The presence of personality disorder can be a determinant of suicidal behavior, predispose the person to major mental disorders such as depressive disorders or alcohol addiction, and cause relationship and social adjustment problems ${ }^{41}$. Therefore, high psychoticism score in SLD, which has a common neurodevelopmental background with schizophrenia, and its prediction of suicidal ideation was an expected result ${ }^{37}$. Because compared to the general population the risk of suicide is 8.5 times higher in patients with psychotic symptoms ${ }^{42}$. The remarkable aspect of our study was not the negative self-evaluation and depressive symptoms that determined the high probability of suicide in the SLD group, but the high level of hopelessness that represented children's negative expectations from the future. In the control group, suicidal ideation was associated with the dimensions of hopelessness, hostility, negative selfevaluation and personality pathology not only limited to psychoticism, but all subscales of personality pathology (except antagonism). 
Evaluation of the entire study population revealed that CDI scores were higher in females. Although some studies reported that the relationship between gender and depression is not significant, other studies have shown that hormonal changes and estrogeninduced brain changes increase sensitivity to stress, which may be the reason for higher depression in female adolescents ${ }^{43}$. In our study, individuals with comorbid somatic diseases were also found to have higher CDI scores and negative affectivity personality subscale scores. Considering human health as a whole, it can be said that having a physical illness also affects the mental state of the person. Depression can worsen the prognosis of a chronic disease or the presence of a chronic disease can cause depression ${ }^{44}$. Because chronic diseases that cause chronic stress may trigger depression ${ }^{45}$. In our study, the presence of diseases affecting the external appearance such as acne vulgaris, obesity, scoliosis, or diseases affecting respiration such as allergic asthma and adenoid hypertrophy, or neurological diseases such as cerebral palsy, epilepsy, and hydrocephalus may have created an additional burden for depression.

The scale scores of the children being treated with neuropsychiatric drugs were high in our study. This situation can be considered as a natural consequence of the need for medical support in children and adolescents with more severe symptoms. However, the scores of negative self-evaluation, suicidal ideation, and personality trait subscales of antagonism and disinhibition of these patients were not high. In particular, it can be said that the combination of SSRI and antipsychotics, which was the most frequently used treatment in our study, helped to reduce the risk of suicide ${ }^{46}$. High rates ADHD comorbidity in the SLD group and the use of psychostimulants in these patients may have reduced impulsivity and risk-taking behaviors in these children and thus contributed to the low disinhibition subscale scores. Because psychostimulants are drugs that improve activity level and impulsivity ${ }^{47}$.

In our study, suicidal ideation and personality pathology scores were higher in children of mothers with a history of smoking during pregnancy. Studies have shown that the majority of children exposed to maternal smoking have a high risk of psychiatric disorder ${ }^{48}$. In addition, it is known that smoking during pregnancy can negatively affect cognitive functions in the child in the long term, decrease academic success, cause alcohol-drug addiction, mood disorders, ADHD, anxiety, anti-social behaviour, and create a tendency to commit criminal crimes in adolescence ${ }^{49-51}$. Pregnancy is a period with high risk for exacerbation of previous psychiatric disorders as well as pregnancy-related depression and anxiety. If psychiatric disorders that occur or exacerbate during pregnancy are not treated, there may be an increase in smoking and alcohol consumption ${ }^{52}$. Studies have found a significant relationship between depression in pregnancy and smoking 51,53 . Despite all these, we did not find any data in the literature regarding the relationship between smoking during pregnancy and personality pathologies and suicide ideation in children. Whether the pregnant woman's predisposition to psychopathology before or during pregnancy leads the mother to smoking, or whether the child's personality pathology or suicidal ideation in the later period is due to the genetic burden of the mother's psychopathology-prone nature regardless of smoking, or whether smoking itself is a risk factor that causes psychiatric pathology is still debatable. Therefore, more comprehensive studies are needed.

One of the limitations of our study was that SLD was not classified in the order of reading, writing, and arithmetic skills difficulties, and the current severity (mild, moderate, severe) was not determined. Another limitation was that the prenatal and perinatal histories of the children and the smoking history of the mothers during pregnancy were based on the maternal anamnesis only.

In the present study, the high probability of suicide in children and adolescents diagnosed with SLD independent of depression, revealed that these children should not only be supported academically, but should also be evaluated in terms of suicide even in cases where depression is not a comorbidity. High levels of personality pathologies also support the importance of questioning temperament traits along with psychiatric comorbidities. It is inevitable that SLD, which is a neurodevelopmental disorder, will be affected by prenatal and perinatal factors. Therefore, in order to ensure normal brain development pregnant women should be supported and educated about the importance of these periods on lives of their children.

Yazar Katkıları: Çalısma konsepti/Tasarımı: DYM, Veri toplama: DYM; Veri analizi ve yorumlama: DYM; Yazı taslağı: DYM; İçeriğin eleștirel incelenmesi: DYM; Son onay ve sorumluluk: DYM, BÖ; Teknik ve malzeme desteği: BÖ; Süpervizyon: DYM; Fon sağlama (mevcut ise): yok.

Etik Onay: Bu çalışma için Yozgat Bozok Üniversitesi Rektörlüğü Klinik Arasturmalar Etik Kurulundan 11.12.2019 tarih ve 2017-KAEK189_2019.12.11_03 saylı kararı ile etik onay alınmıștır. 


\section{Hakem Değerlendirmesi: Dıs bağımsız.}

Çıar Çatışması: Yazarlar çıkar çatısması beyan etmemişlerdir. Finansal Destek: Yazarlar finansal destek beyan etmemişlerdir. Author Contributions: Concept/Design : DYM; Data acquisition: DYM; Data analysis and interpretation: DYM; Drafting manuscript: DYM; Critical revision of manuscript: DYM; Final approval and accountability: DYM, BÖ; Technical or material support: BÖ; Supervision: DYM; Securing funding (if available): $\mathrm{n} / \mathrm{a}$. Ethical Approval: Ethical approval for this study was obtained from the Clinical Research Ethics Committee of Yozgat Bozok University, with the decision dated 11.12.2019 and numbered 2017-KAEK189_2019.12.11 03 .

Peer-review: Externally peer-reviewed

Conflict of Interest: Authors declared no conflict of interest.

Financial Disclosure: Authors declared no financial support

\section{REFERENCES}

1. American Psychiatric Association. Diagnostic and Statistical Manual of Mental Disorders $5^{\text {th }}$ edition (DSM-5 ). Washington DC, American Psychiatric Association. 2013.

2. Bender WN. Öğrenme Güçlüğü Olan Bireyler ve Eğitimleri: Özellikleri, Tanılama ve Öğretim Stratejileri (Çeviri Ed H. Sarı). Ankara, Nobel. 2014.

3. Sahoo MK, Biswas H, Padhy SK. Psychological comorbidity in children with specific learning disorders. J Family Med Prim Care. 2015; 4(1):21.

4. Bandla S, Mandadi GD, Bhogaraju A. Specific learning disabilities and psychiatric comorbidities in school children in South India. Indian J Psychol Med. 2017;39:76-82.

5. American Psychiatric Association. Diagnostic and Statistical Manual of Mental Disorders $4^{\text {th }}$ edition (DSM-IV ).Washington DC, American Psychiatric Association, 2004

6. Srinath S, Girimaji SC, Gururaj G, Seshadri S, Subbakrishna DK, Bhola P et al. Epidemiological study of child\&adolescent psychiatric disorders in urban \&rural areas of Bangalore, India. Indian J Med Res. 2005;122:67.

7. Mason A, Mason M. Understanding college students with learning disabilities. Pediatr Clin North Am. 2005;52:61-70.

8. Swanson HL, Hsieh CJ. Reading disabilities in adults: a selective meta-analysis of the literature. Rev Educ Res. 2009;79:1362-90.

9. Tsitsas G. How personality traits relate to the selfesteem of Greek children and adolescents with dyslexia. J Pedagog Dev. 2017;7:1-14.

10. Pennington BF, Mcgrath LM, Rosenberg J, Barnard $\mathrm{H}$, Smith SD, Willcutt EG et al. Gene x environment interactions in reading disability and attentiondeficit/hyperactivity disorder. Dev Psychol. 2009;45:77-89.

11. Ay R, Erbay LG. Relationship between childhood trauma and suicide probability in obsessivecompulsive disorder. Psychiatry Res. 2018;261:132-6.

12. Soysal Ş, Koçkar Aİ, Erdoğan E, Şenol S, Gücüyener $\mathrm{K}$. Öğrenme güçlüğü olan bir grup hastanın WISC-R profillerinin incelenmesi. Klinik Psikiyatri Dergisi. 2001;4:225-31.

13. Kaufman J, Birmaher B, Brent D, Rao U, Flynn C, Moreci $\mathrm{P}$ et al. Schedule for affective disorders and schizophrenia for school-age children-present and lifetime version (KSADS-PL): initial reliability and validity data. J Am Acad Child Adolesc Psychiatry. 1997;36:980-8

14. Gokler B, Unal F, Pehlivanturk B, Cengel Kultur E, Devrim Akdemir D, Taner Y. Reliability and validity of Schedule for affective disorders and schizophrenia for school age children - present and lifetime version -Turkish version (K-SADS-PL-T). Turk J Child Adol Mental Health. 2004;11:109-16.

15. Uluç S, Öktem F, Erden G, Gençöz T, Sezgin N. Wechler intelligence scale for children-IV: A new era for Turkey in evaluation of intelligence in the clinical context. Turk Psikoloji Yazıları. 2011;14(28):49-57.

16. Savașır I, Şahin N: Weschler Çocuklar Için Zekâ Ölçeği. Ankara, Türk Psikologlar Derneği, 1995.

17. Kovacs M. The children's depression, inventory (CDI). Psychopharmacol Bull. 1985;21:995-8.

18. Öy, B. Çocuklar için depresyon ölçeği: Geçerlilik ve güvenlik çalışması. Turk Psikiyatri Derg. 1991;2:1326.

19. Cull JG, Gill WS. Suicide Probability Scale. Western Psychological Services, Los Angeles, 1990.

20. Atli Z, Eskin M, Dereboy C. The validity and the reliliability of suicide probability scale (SPS) in clinical sample. J Clin Psychiatry. 2009;12:111-24.

21. Krueger RF, Eaton NR, Clark LA, Watson D, Markon $\mathrm{KE}$, Derringer J et al. Deriving an empirical structure of personality pathology for DSM-5. J Pers Disord. 2011;25:170-91.

22. Yalın Sapmaz Ş, Özek Erkuran H, Uzel Tanriverdi B, Öztürk M, Köroğlu E, Aydemir Ö. Reliability and Validity of Turkish DSM-5 Personality Inventory Child Form. Istanbul, Turkey, 2017.

23. Manning FA, Hohler C. Intrauterine growth retardation: diagnosis, prognostication, and management based on ultra-sound methods, in Fleisher AÇ, Romero R, Manning FA et al. The Principles and Practices and Ultrasonography. 4th. ed., Norwalk: CT Appleton and Lange, 1991;331.

24. Kovachy VN, Adams JN, Tamaresis JS, Feldman HM. Reading abilities in school-aged preterm children: a review and meta-analysis. Dev Med Child Neurol. 2015;57:410-9.

25. Kempe C, Gustafson S, Samuelsson S. a longitudinal study of early reading difficulties and subsequent problem behaviors. Scand J Psychol. 2011;52:242-50.

26. Yıldız SA. Öğrenme güçlüğü olan çocukların psikososyal özellikleri, sorunları ve eğitimi. Hasan Ali Yücel Eğitim Fakültesi Dergisi. 2004;2:169-80.

27. Deniz ME, Yorgancı Z, ve Özyeşil Z. Öğrenme güçlüğü görülen çocukların sürekli kaygı ve depresyon düzeylerinin incelenmesi üzerine bir araştırma. İlköğretim Online. 2009;8:694-708. 
28. Schonfeld DJ \& Demaria T. Providing psychosocial support to children and families in the aftermath of disasters and crises. Pediatrics. 2015;136:1120-30.

29. WilburnVR, Smith DE. Stres, self-esteem and suicidal ideation in late adolescents. Adolescence. 2005;40:3345.

30. Brezo J, Paris J, Turecki G. Personality traits as correlates of suicidal ideation, suicide attempts, and suicide completions: asystematic review. Acta Psychiatr Scand. 2006;113:180-206.

31. Stewart SM, Kennard BD, Lee P, W Mayes T, Hughes C, Emslie G. Hopelessness and suicidal ideation among adolescent in two cultures., J Child Psychol Psychiatry. 2005;46:364-72.

32. Görgülü T, Kışlak ŞT. Submissive behaviours, depression and suicide probability in male arrestees and convicts. Noro Psikiyatri Ars. 2014;51:40-5.

33. Sharma G. A comparative study of the personality characteristics of primary school students with learning disabilities and their non-learning disabled peers. Learn Disabil Q. 2004;27:127-40.

34. Watson D, Stasik SM, Ro E, Clark LA. Integrating normal and pathological personality relating the DSM5 trait-dimensional model to general traits of personality. Assessment. 2013;20:312-26.

35. De Hirsch K, Janaky JJ. Patterning and organizational deficits in children with language and learning disabilities. Bulletin of the Orton Society. 1980;30:227-39.

36. Richardson AJ, Stein JF. Personality characteristics of adult dyslexics (Wright and R. Groner). Facets of Dyslexia and its Remediation. Amsterdam, Elsevier/North-Holland Science Publishers, 1993;411-23.

37. Roberts EO, Proudlock FA, Martin K, Reveley MA, Al-Uzri M, Gottlob I. Reading in schizophrenic subjects and their nonsymptomatic first-degree relatives. Schizophr Bull. 2013;39:896-907.

38. Migden SD. Dyslexia and self control: An ego psychoanalytic perspective. Psychoanalytic Study of the child. 1998;53:282-99.

39. Borum R, Bartel P, Forth A. SAVRY: Manual for the structured assessment of violence risk in youth. University of South Florida, 2003.

40. Peters EM, Balbuena L, Marwaha S, Baetz M, Bowen R. Mood instability and impulsivity as trait predictors ofsuicidal thoughts. Psychol Psychother. 2016;89:435-44.

41. Kaplan HI, Sadock BJ. Clinical Psychiatry (Çeviri Ed E Abay). İstanbul, Nobel Matbaacillk, 2004.

42. American Psychiatric Association. Practice Guidelines Assessment and Treatment of Patients with Suicidal Behaviors. Washington DC, American Psychiatric Association, 2003.

43. Thapar A, Collishaw S, Pine DS, Thapar AK. Depression in adolescence. Lancet. 2012;17:1056-67.

44. Mete HE. Chronic illness and depression. Clinical Psychiatry. 2008;11:3-18.

45. Stalder T, Steudte-Schmiedgen S, Alexander N, Klucken T, Vater A, Wichmann S et al. Stress-related and basic determinants of hair cortisol in humans: a meta-analysis. Psychoneuroendocrinology. 2017;77:261-74.

46. Pompili M, Ruberto A, Kotzalidis GD, Girardi P, Tatarelli R. Suicide and awareness of illness in schizophrenia: an overview. Bull Menninger Clin. 2004;68:297-318.

47. Santosh P, Taylor E. Stimulant drugs. Eur Child Adolesc Psychiatry. 2000;9:27-43.

48. Ekblad M, Gissler M, Lehtonen L, Korkeila J. Prenatal smoking exposure and the risk for psychiatric morbidity into young adulthood. Arch Gen Psychiatry. 2010;67:841-9.

49. Fegusson DM, Woodward LJ and Harwood. Maternal smoking during pregnancy and psychiatric adjustment in late adolesence. Arch Gen Psychiatry. 1998;55:7217.

50. Brennan PA, Grekin ER, Mednick SA. Maternal smoking during pregnancy and adultmale criminal outcomes. Arch Gen Psychiatry. 1999;56:215-9.

51. Öberg M, Jaakkola MS, Prüss-Üstün A, Schweizer C, Woodward A. Second-handsmoke: Assessing the environmental burden of disease at national and local levels. WHO Environmental Burden of Disease Series. Geneva, World Health Organization, 2010.

52. Cebeci S, Aydemir Ç, Göka E. Depression symptom prevalence in puerperal period: obstetric risk factors, anxiety. Kriz Dergisi. 2002;10:11-18.

53. Yanıkkerem E, Atlan E, Demirtosun P. Depression in pregnant women living in the Manisa No.1 health center area. Obstetrics Journal. 2004;2:301-6. 